\title{
Primary production and community respiration in the Humboldt Current System off Chile and associated oceanic areas
}

\author{
Giovanni Daneri ${ }^{1, *}$, Victor Dellarossa ${ }^{2}$, Renato Quiñones ${ }^{3}$, Barbara Jacob ${ }^{1}$, \\ Paulina Montero ${ }^{1}$, Osvaldo Ulloa ${ }^{4}$ \\ ${ }^{1}$ Centro de Ciencias y Ecología Aplicada (CEA), Universidad del Mar. Campus Valparaíso, Carmen 446, Placeres, \\ Valparaíso, Chile \\ ${ }^{2}$ Departamento de Botánica, ${ }^{3}$ Departamento de Oceanografía and ${ }^{4}$ Programa Regional de Oceanografía Física y Clima, \\ Universidad de Concepción, Casilla 2407, Concepción, Chile
}

\begin{abstract}
The high biological productivity of the Humboldt Current System (HCS) off Chile supports an annual fish catch of over 7 million t. The area is also important biogeochemically, because the outgassing of recently upwelled water is modulated by contrasting degrees of biological activity. However, very few field measurements of primary production and planktonic respiration have been undertaken within the Eastern Boundary Current (EBC) system off Chile. In this study an estimate of primary production (PP) and surface planktonic community respiration is presented from several research cruises in the HCS and adjacent oceanic areas. The highest production levels were found near the coast correlating closely with known upwelling areas. Both gross primary production (GPP) and community respiration (CR) showed important spatial and temporal fluctuations. The highest water column integrated GPP was measured in the southern and central fishing area $\left(19.9 \mathrm{~g} \mathrm{C} \mathrm{m}^{-2} \mathrm{~d}^{-1}\right)$ and off the Antofagasta upwelling ecosystem $\left(9.3 \mathrm{~g} \mathrm{C} \mathrm{m}^{-2} \mathrm{~d}^{-1}\right)$. The range of GPP agrees well with values reported for Perú $\left(0.05\right.$ to $\left.11.7 \mathrm{~g} \mathrm{C} \mathrm{m}^{-2} \mathrm{~d}^{-1}\right)$. The Coquimbo upwelling system, despite being an area of persistent upwelling, showed lower production and community respiration values than the Antofagasta and Concepcion Shelf areas. The lowest surface PP values were measured within the oceanic region adjacent to the northern coastal upwelling zones $\left(0.8 \pm 0.5 \mu \mathrm{g} \mathrm{Cl}^{-1} \mathrm{~h}^{-1}\right)$, though slightly enhanced biological production was found within the Nazca Ridge $\left(1.5 \pm 2.1 \mu \mathrm{g} \mathrm{C} \mathrm{I}^{-1} \mathrm{~h}^{-1}\right)$ that separates the Chilean and Peruvian deep basins.
\end{abstract}

KEY WORDS: Humboldt Current System - Upwelling · Primary production

\section{INTRODUCTION}

The Eastern Boundary Current (EBC) off Chile is a system that shares many of the mesoscale and local features which typify continental eastern margins. Among the most conspicuous are the occurrence of coastal upwelling, the presence of a shallow nutrient-rich subsurface water mass devoid of oxygen, and strong interannual variation associated with El Niño Southern Oscillation (ENSO) events. The very long

•E-mail: gdaneri@udelmar.cl latitudinal range and the highly diverse topography of the coastline and continental shelf makes the Chilean EBC system highly heterogeneous. In its southern part the Chilean EBC presents a marked meteorological seasonality, while the central and northern regions exhibit moderate and dampened seasonality respectively. Associated with these seasonal and latitudinal changes in hydrodynamics, switches in the biological production rates occur, as evidenced by measurements of chlorophyll a ( $\mathrm{chl}$ a) concentration, phytoplankton counting and analyses of mesozooplankton samples (Peterson et al. 1988, Ahumada 1989) 
Upwelling events have been described as the main feature controlling primary production (PP) and biomass levels within EBC systems. During upwelling events subsurface waters are transported into the photic zone, promoting high levels of PP and phytoplankton concentration. A close coupling between upwelling events and PP and/or pigment composition is expected in coastal upwelling areas. However, the relationship between upwelling and enhanced biological production is not always clear. Thomas et al. (1994) showed that pigments appear to be tightly coupled to coastal winds in the Eastern North Pacific Current System. A similar study undertaken by the same authors in the Humboldt Current System (HCS) showed a poor correlation between local winds and phytoplankton biomass, strongly suggesting that other forcing may have to be considered (Arcos \& Salamanca 1984, Jury et al. 1990).

The high biological productivity of the HCS off Chile supports an annual fish catch of over 7 million $t$. Generally, it is accepted that the basis for this high biological production is the occurrence of coastal upwelling (Alheit \& Bernal 1993). The main source of upwelling water in the HCS off Chile is the Subsurface Equatorial Water (AESS, Agua Ecuatorial Subsuperficial) (Morales et al. 1996 and references therein) associated with the Peru-Chile Undercurrent. AESS is characterised by its low oxygen content and high inorganic nutrient concentration (Silva \& Konow 1975, Bernal et al. 1982). Upwelling pulses of AESS followed by periods of relaxation of the wind stress probably represent the best conditions for stimulating phytoplankton growth (Peterson et al. 1988, Marín et al. 1993). Nevertheless, there is a growing realisation that the above conditions are only 1 factor determining the levels of PP in the HCS off Chile. Depending on the hydrodynamical conditions, wind-induced mixing of the water column may result in upwelling of water masses with different characteristics, generating distinct fertilising effects (Morales et al. 1996). Enhanced biological production may also be triggered by remotely forced changes in water column conditions such as water column mixing induced by sea floor topography (Arcos \& Salamanca 1984). Despite the importance of the HCS off Chile there are very little data on PP and the factors that control it, although some of the PP values are among the highest ever reported in the literature (Marin et al. 1993, Fossing et al. 1995).

In this paper measurements of PP and planktonic community respiration (CR) of the HCS off Chile and adjacent areas collected during several research cruises are reported. Specifically, an analysis of $\mathrm{PP}$ and $C R$ is used to define areas of contrasting biological production within the HCS off Chile and adjacent oceanic areas. The spatio-temporal covering of the information gathered allowed, for the first time, an annual estimation of PP for the Central and South sections of the HCS.

\section{MATERIAL AND METHODS}

The study area corresponded to the HCS off Chile and its adjacent oceanic areas (Fig. 1). Several research cruises (Table 1) were conducted during this study and sampling included El Niño and non-El Niño conditions. Sampling took place in Antofagasta $\left(22^{\circ} \mathrm{S}\right)$, Coquimbo $\left(30^{\circ} \mathrm{S}\right)$ and Concepción Shelf $\left(36^{\circ} \mathrm{S}\right)$ coastal upwelling sites on board the RV 'Abate Molina' as part of the JGOFS-Chile, Sectorial-CONICYT Antofagasta and FONDAP-Humboldt research programs. The JGOFS-Chile (Coquimbo area) results are from a fixed coast to offshore transect running from the Coquimbo coastal station (COSMOS) $\left(30^{\circ} 20^{\prime} 90^{\prime \prime} \mathrm{S}, 71^{\circ} 47^{\prime} 40^{\prime \prime} \mathrm{W}\right)$ to OCEMOS $\left(29^{\circ} 58^{\prime} 02^{\prime \prime} \mathrm{S}\right.$, $\left.73^{\circ} 19^{\prime} 18^{\prime \prime} \mathrm{W}\right)$. This transect was sampled in July 1996 , February 1997 and November 1997. The Antofagasta upwelling area was visited in January 1997, July 1997 and January 1998. In Antofagasta stations were sampled within a grid bounded by $22^{\circ} 40^{\prime} \mathrm{S}$ to $24^{\circ} 00^{\prime} \mathrm{S}$ and $70^{\circ} 30^{\prime} \mathrm{W}$ to $71^{\circ} 52^{\prime} \mathrm{W}$. The Concepción Shelf upwelling area was sampled in October 1998. More oceanic

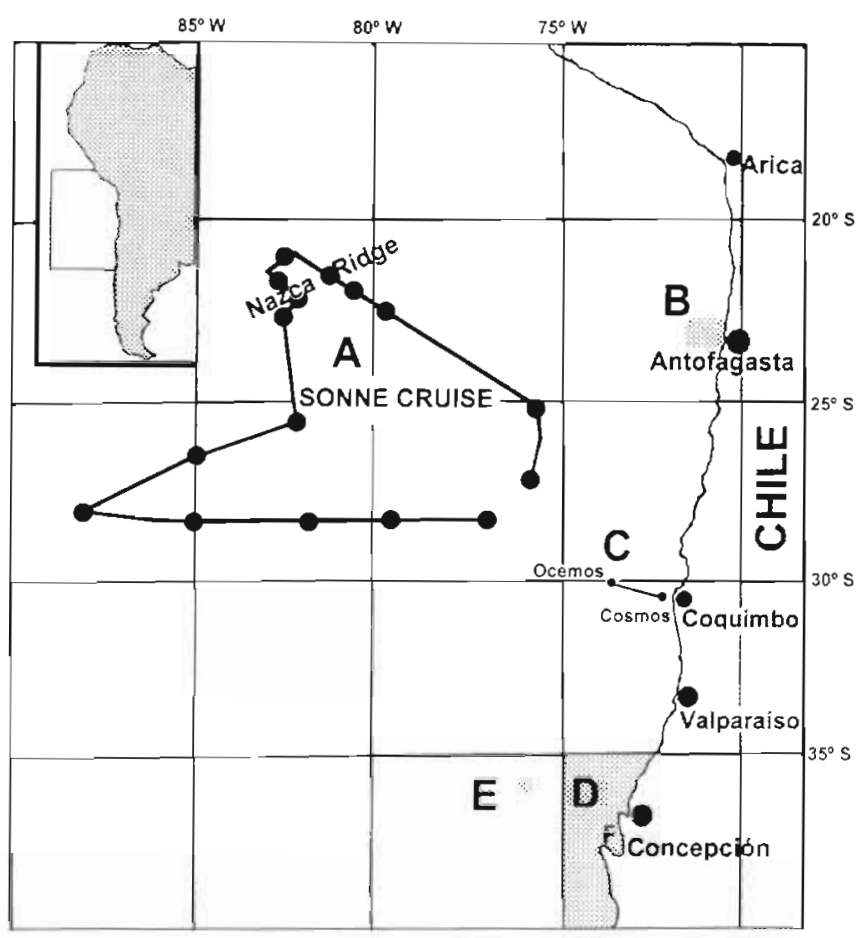

Fig. 1. Area sampled. (A) 'Sonne' cruise track, (B) Antofagasta upwelling ecosystem, (C) Coquimbo upwelling ecosystem, (D) Central-South fishing area, (E) 200 miles offshore Concepción Station, (F) Arauco Gulf 
Table 1. Summary of research cruises conducted in the Eastern Boundary Current off Chile

\begin{tabular}{|c|c|c|c|}
\hline Mo & $\mathrm{Yr}$ & Vessel & Area sampled \\
\hline & $1989-1991^{d}$ & FV 'Don Nordlund' & Central-South fishing area \\
\hline Jun & 1995 & RV 'Sonne' & Adjacent oceanic areas \\
\hline Jul & 1996 & RV 'Abate Molina' & Coquimbo upwelling system \\
\hline Jan & 1997 & RV 'Abate Molina' & Antofagasta upwelling system \\
\hline Feb & 1997 & RV 'Abate Molina' & Coquimbo upwelling system \\
\hline July & 1997 & RV 'Abate Molina' & Antofagasta upwelling system \\
\hline Nov $^{b}$ & 1997 & RV 'Abate Molina' & Coquimbo upwelling system \\
\hline $\operatorname{Jan}^{b}$ & 1998 & RV 'Abate Molina' & Antofagasta upwelling system \\
\hline Oct & 1998 & RV 'Abate Molina' & Concepción upwelling system \\
\hline
\end{tabular}

stations were sampled during June 1995 on board the RV 'Sonne' within an area bounded approximately by $20^{\circ} 00^{\prime} \mathrm{S}$ to $30^{\circ} 00^{\prime} \mathrm{S}$ and $75^{\circ} 00^{\prime} \mathrm{W}$ to $90^{\circ} 00^{\prime} \mathrm{W}$. Fig. 1 shows part of the cruise track and the stations visited during the RV 'Sonne' cruise.

PP data from the Central-South fishing area, which includes the Concepción upwelling ecosystem area, of Chile (Fig. 1) were also gathered during the 1989 to 1991 period. Sampling took place on board of the fishing vessel 'Don Nordlund' and covered and area bounded by $35^{\circ} 00^{\prime} \mathrm{S}$ to $39^{\circ} 00^{\prime} \mathrm{S}$ and $73^{\circ} 00^{\prime} \mathrm{W}$ to $75^{\circ} 00^{\prime} \mathrm{W}$.

Sample collection. During the cruises on board the RV 'Abate Molina' to the Antofagasta, Coquimbo and Concepción Shelf upwelling sites, samples for surface and water column PP and CR measurements were collected using Niskin bottles attached to a CTD rosette. The Niskin bottles were acid washed at the beginning of the cruises. During the cruise on board the RV 'Sonne' to the oceanic area, samples for surface water column PP and CR measurements were obtained using a bucket.

Hydrographic and optical measurements. At each station, water column temperature and salinity were measured using a CTD (Neil Brown Mark III). Temperature readings were calibrated against discrete measurements using reversing thermometers. The conductivity was calibrated against salinity samples obtained at discrete depths and analysed with a salinometer (Autosal 2000). Photosynthetically active radiation (PAR) was measured using a $4 \pi$ light sensor (Biospherical Co.). The depth of the euphotic zone was determined as the light depth at which the scalar PAR fell to $1 \%$ of the surface values.

Chlorophyll a (chl a). Chl a was estimated using a Turner Designs fluorometer model 10AU calibrated against pure chl a (Sigma Co.) following the method of Holm-Hansen et al. (1965). Pigments were extracted on board in cold acetone (90\%) for $24 \mathrm{~h}$ and fluorescence was measured before and after acidification.
In vitro gross primary production (GPP) and $C R$ measurements. PP and CR were estimated from changes in dissolved oxygen concentrations incubating in vitro light and dark bottles (Strickland 1960). Water from the rosette was dispensed using a silicone tube to 15 borosilicate bottles ( $125 \mathrm{ml}$ nominal value) distributed in the following way: 5 initial bottles, 5 light bottles and 5 dark bottles. In vitro surface samples were incubated in on-deck incubators made of Perspex which allowed the penetration of $80 \%$ surface PAR. The temperature was controlled by circulating surface seawater through the incubators. Dissolved oxygen concentration was measured using a semi-automatic version of the Winkler method (Williams \& Jenkinson 1982, Knap et al. 1993) based on an end-point photometric detector, a Dosimat 665 (Metrohom) and a chart recorder. The entire contents of the bottle were titrated. Incubations were carried out from dawn to dusk and the precision was in the range of \pm 0.05 to $0.3 \mu \mathrm{mol} \mathrm{l}^{-1}$. GPP values measured in $\mu \mathrm{mol} \mathrm{O} \mathrm{l}^{-1} \mathrm{~h}^{-1}$ were converted to $\mu \mathrm{g} \mathrm{Cl}^{-1}$ $\mathrm{h}^{-1}$ using a theoretical conservative $\mathrm{PQ}$ of 1.25 in the case of the coastal samples and 1 in the case of oligotrophic oceanic samples. The $\mathrm{CR}$ values were converted from oxygen to carbon units using an RQ of 1.

Mixed layer integrated GPP and CR. Daily mixed layer integrated GPP and CR were estimated by multiplying the surface GPP and CR values by the depth of the mixed layer. This was only done in stations where primary production values obtained from ${ }^{14} \mathrm{C}$ measurements, made at more than 2 depths within the mixed layer (J. L. Iriarte unpubl.), were found to be identical.

In situ water column daily integrated GPP and CR. Daily in situ water column integrated GPP and $C R$ were estimated by collecting water samples from light depth corresponding to $100,80,53,32,8$ and $1 \%$ of surface incident PAR light. Samples from each depth were dispensed in glass bottles $(125 \mathrm{ml}$ nominal volume) and incubated as 5 dark and 5 light in a drifting 
array. Water collection took place at dawn while the retrieving of the array from the water was done at dusk. During the in situ incubation, the RV 'Abate Molina' stayed within sight of the drifting array. A total of 10 in situ experiments were performed during this study. During July 1997 in Antofagasta at 1 station $\left(23^{\circ} 20^{\prime} 37^{\prime \prime} \mathrm{S}, 70^{\circ} 42^{\prime} 66^{\prime \prime} \mathrm{W}\right)$; during November 1997 in Coquimbo at 2 stations (COSMOS: $30^{\circ} 20^{\prime} 90^{\prime \prime} \mathrm{S}$, $71^{\circ} 47^{\prime} 40^{\prime \prime} \mathrm{W}_{\text {; }}$ and OCEMOS: $\left.29^{\circ} 58^{\prime} 02^{\prime \prime} \mathrm{S}, 73^{\circ} 19^{\prime} 18^{\prime \prime} \mathrm{W}\right)_{i}$ during January 1998 in Antofagasta at 3 stations (Stn 1: $22^{\circ} 47^{\prime} 20^{\prime \prime} \mathrm{S}, 70^{\circ} 32^{\prime} 38^{\prime \prime} \mathrm{W}$; Stn 2: $22^{\circ} 42^{\prime} 95^{\prime \prime} \mathrm{S}$, $70^{\circ} 36^{\prime} 48^{\prime \prime} \mathrm{W}$; and $\mathrm{Stn} 3$; $22^{\circ} 47^{\prime} 64^{\prime \prime} \mathrm{S}, 70^{\circ} 24^{\prime} 83^{\prime \prime} \mathrm{W}$ ) and in October 1998 in the Concepción Shelf area at 3 stations (Stn 1: $36^{\circ} 52^{\prime} 60^{\prime \prime} \mathrm{S}, 73^{\circ} 53^{\prime} 70^{\prime \prime} \mathrm{W}$; Stn 2:

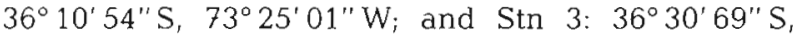
$\left.73^{\circ} 09^{\prime} 10^{\prime \prime} \mathrm{W}\right)$ and 1 station 200 miles $(-312.8 \mathrm{~km})$ offshore of Concepción $\left(36^{\circ} 19^{\prime} 85^{\prime \prime} \mathrm{S}, 76^{\circ} 58^{\prime} 66^{\prime \prime} \mathrm{W}\right)$. The daily in situ integrated CR values were calculated by multiplying the daylight respiration rates to account for a $24 \mathrm{~h}$ period. To our knowledge this constitutes the first reported effort to measure in situ GPP and CR in the EBC system off Chile.

In the cruises on board the fishing vessel (FV) 'Don Nordlund' water samples were collected using Van Dorm $5 \mathrm{l}$ bottles from depths corresponding to the 80 , 53, 32, 8 and $1 \%$ of surface incident light depth. PP was estimated using on-deck incubators with circulating surface water or in the laboratory in simulated light gradients. The incubating temperature in the laboratory was on average 1 to $2^{\circ} \mathrm{C}$ warmer than the sea surface temperature (SST) of the water column sampled. Laboratory incubations were performed when the cruise did not last more than $12 \mathrm{~h}$. Results from the simulated light gradient incubations were converted to daily production rates using the model described by Fee (1984) adapted to the annual radiation cycle of the Bay of Concepcion. The radiation values were obtained from the meteorological station 'Bellavista' of the University of Concepción. PP was estimated using a combination of ${ }^{14} \mathrm{C}$ (samples with chl $a<2 \mu \mathrm{g} \mathrm{l}^{-1}$; Strickland \& Parsons 1972) and the Winkler oxygen light and dark bottles technique (samples with chl $a>$ $2 \mu \mathrm{g} \mathrm{I}^{-1}$; Carrit \& Carpenter 1966). To convert the values obtained in $\mu \mathrm{mol} \mathrm{O}_{2} \mathrm{1}^{-1} \mathrm{~h}^{-1}$ an experimentally derived PQ of 1.5 was employed.

\section{RESULTS}

\section{Surface GPP and CR}

The mean surface GPP and CR values measured in Antofagasta, Coquimbo and adjacent oceanic regions obtained during this study ranged from 0.4 to 97.8 and 0.0 to $16.7 \mu \mathrm{g} \mathrm{C}{ }^{-1} \mathrm{~h}^{-1}$ respectively (Table 2 ). In the
Table 2. Mean surface gross primary production (GPP) and community respiration (CR) measured in Antofagasta $\left(22^{\circ} \mathrm{S}\right)$ and Coquimbo $\left(30^{\circ} \mathrm{S}\right)$

\begin{tabular}{|c|c|c|}
\hline $\operatorname{GPP}\left(\mu g \mathrm{C}^{-1} \mathrm{~h}^{-1}\right)$ & $\mathrm{X} \pm \mathrm{SD}$ & Range \\
\hline \multicolumn{3}{|l|}{ Upwelling systems } \\
\hline Coquimbo (Jul 1996) & $4.4 \pm 3.7$ & $(0.8-9.4, n=4)$ \\
\hline Coquimbo (Feb 1997) & $12.0 \pm 7.2$ & $(4.2-29.9, n=7)$ \\
\hline Antofagasta (Jan 1997) & $22.1 \pm 25.9$ & $(0.8-97.8, \mathrm{n}=23)$ \\
\hline Antofagasta (Jul 1997) & $7.5 \pm 5.6$ & $(3.1-26.0, n=15)$ \\
\hline \multicolumn{3}{|l|}{ Adjacent oceanic } \\
\hline Oceanic region & $0.7 \pm 0.4$ & $(0.4-1.4, \mathrm{n}=8)$ \\
\hline Nazca ridge & $1.8 \pm 1.2$ & $(0.5-3.7, n=6)$ \\
\hline$C R\left(\mu g C I^{-1} h^{-1}\right)$ & $X \pm S D$ & Range \\
\hline \multicolumn{3}{|l|}{ Upwelling systems } \\
\hline Coquimbo (Jul 1996) & $2.1 \pm 2.3$ & $(0.8-5.6, n=4)$ \\
\hline Coquimbo (Feb 1997) & $2.8 \pm 1.2$ & $(0.7-5.6, n=11)$ \\
\hline Antofagasta (Jan 1997) & $7.3 \pm 5.3$ & $(0.0-16.7, n=23)$ \\
\hline Antofagasta (Jul 1997) & $2.3 \pm 2.0$ & $\{0.0-4.4, \mathrm{n}=15\}$ \\
\hline \multicolumn{3}{|l|}{ Adjacent oceanic } \\
\hline Oceanic Region & $0.8 \pm 0.5$ & $(0.05-1.8, n=8)$ \\
\hline Nazca Ridge & $1.5 \pm 2.1$ & $(0.4-5.8, n=6)$ \\
\hline
\end{tabular}

Antofagasta upwelling area, during January 1997 (preEl Nin̄o conditions), mean surface GPP values of $22.1 \pm$ $25.9 \mu \mathrm{g} \mathrm{Cl}^{-1} \mathrm{~h}^{-1}$ and mean $\mathrm{CR}$ values of $7.3 \pm 5.3 \mu \mathrm{g} \mathrm{C}$ $\mathrm{l}^{-1} \mathrm{~h}^{-1}$ were measured. In the same area, during July 1997 (El Niño conditions) mean surface GPP and CR were $6.4 \pm 5.7$ and $2.1 \pm 1.8 \mu \mathrm{g} \mathrm{C} \mathrm{l}^{-1} \mathrm{~h}^{-1}$ respectively. A statistical comparison using a student's t-test revealed significant differences (at the 95\% level) between the mean surface GPP and CR values measured in January 1997 and July 1997

The average surface GPP and CR values obtained in Coquimbo during July 1996 were $4.41 \pm 3.7$ and $2.71 \pm$ $2.34 \mu \mathrm{g} \mathrm{C} \mathrm{l}^{-1} \mathrm{~h}^{-1}$, respectively (Table 2). For the same area during pre-El Nino conditions (February 1997) average GPP and CR values of $12.01 \pm 2.34$ and $2.84 \pm$ $1.24 \mu \mathrm{C} \mathrm{Cl}^{-1} \mathrm{~h}^{-1}$ were obtained (Table 2).

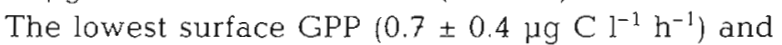
$\mathrm{CR}\left(0.8 \pm 0.5 \mu \mathrm{g} \mathrm{C} \mathrm{l}^{-1} \mathrm{~h}^{-1}\right)$ values were measured in the oceanic region visited during the RV 'Sonne' cruise (Fig. 1). Slightly enhanced biological activity was found in the Nazca Ridge zone (GPP: $1.8 \pm 1.2 \mu \mathrm{g} \mathrm{C} \mathrm{l}^{-1}$

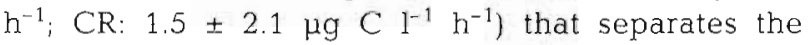
Chilean and Peruvian deep basins (Fig. 1).

\section{Mixed layer and water column daily integrated GPP and CR}

Table 3 shows the mixed layer and water column daily integrated GPP and CR measured in the Antofa- 
Table 3. Mixed layer and water column integrated gross primary production (GPP) and community respiration (CR) measured in Antofagasta $\left(22^{\circ} \mathrm{S}\right)$, Coquimbo $\left(30^{\circ} \mathrm{S}\right)$ and Concepción $\left(36^{\circ} \mathrm{S}\right)$

\begin{tabular}{|c|c|c|c|c|c|}
\hline $\begin{array}{l}\text { Date } \\
\text { (d/mo/yr) }\end{array}$ & Location & $\begin{array}{c}\text { Latitude } \\
\left({ }^{\circ} \mathrm{S}\right)\end{array}$ & $\begin{array}{l}\text { Longitude } \\
\left.\qquad{ }^{\circ} W\right)\end{array}$ & GPP & $\begin{array}{c}C R \\
\left(\mathrm{~g} C \mathrm{~m}^{-2} \mathrm{~d}^{-1}\right)\end{array}$ \\
\hline \multicolumn{6}{|c|}{ Mixed layer integrated PP and CR } \\
\hline $13 / 01 / 97$ & Antofagasta & $23^{\circ} 00^{\prime} 16^{\prime \prime}$ & $71^{\circ} 01^{\prime} 90^{\prime \prime}$ & 0.42 & 0.40 \\
\hline $17 / 01 / 97$ & Antofagasta & $23^{\circ} 14^{\prime} 24^{\prime \prime}$ & $71^{\circ} 56^{\prime} 43^{\prime \prime}$ & 0.12 & 0.06 \\
\hline $25 / 01 / 97$ & Antofagasta & $23^{\circ} 40^{\prime} 07^{\prime \prime}$ & $71^{\circ} 02^{\prime} 58^{\prime \prime}$ & 0.14 & 0.06 \\
\hline $29 / 01 / 97$ & Antofagasta & $23^{\circ} 21^{\prime} 11^{\prime \prime}$ & $70^{\circ} 45^{\prime} 26^{\prime \prime}$ & 9.30 & 1.60 \\
\hline \multicolumn{6}{|c|}{ Water column integrated GPP and CR } \\
\hline $22 / 07 / 97$ & Antofagasta & $23^{\circ} 20^{\prime} 37^{\prime \prime}$ & $70^{\circ} 42^{\prime} 66^{\prime \prime}$ & 2.17 & $1.58^{\circ}$ \\
\hline $05 / 11 / 97$ & COSMOS & $30^{\circ} 20^{\prime} 90^{\prime \prime}$ & $71^{\circ} 47^{\prime} 40^{\prime \prime}$ & 2.80 & $1.46^{\mathrm{b}}$ \\
\hline $07 / 11 / 97$ & OCEMOS & $29^{\circ} 58^{\prime} 02^{\prime \prime}$ & $73^{\circ} 19^{\prime} 18^{\prime \prime}$ & 0.66 & $0.80^{b}$ \\
\hline $26 / 01 / 98$ & Antofagasta & $22^{\circ} 47^{\prime} 20^{\prime \prime}$ & $70^{\circ} 32^{\prime} 38^{\prime \prime}$ & 0.8 & $2.80^{\mathrm{A}}$ \\
\hline $27 / 01 / 98$ & Antofagasta & $22^{\circ} 42^{\prime} 95^{\prime \prime}$ & $70^{\circ} 36^{\prime} 48^{\prime \prime}$ & 1.1 & $1.20^{\mathrm{d}}$ \\
\hline $28 / 01 / 98$ & Antofagasta & $22^{\circ} 47^{\prime} 64^{\prime \prime}$ & $70^{\circ} 24^{\prime} 83^{\prime \prime}$ & 5.1 & $2.60^{d}$ \\
\hline $19 / 10 / 98$ & Concepción & $36^{\circ} 52^{\prime} 60^{\prime \prime}$ & $73^{\circ} 53^{\prime} 70^{\prime \prime}$ & 1.2 & 3.20 \\
\hline $20 / 10 / 98$ & Concepción & $36^{\circ} 10^{\prime} 54^{\prime \prime}$ & $73^{\circ} 25^{\prime} 01^{\prime \prime}$ & 5.3 & 3.20 \\
\hline $22 / 10 / 98$ & Concepción & $36^{\circ} 30^{\prime} 69^{\prime \prime}$ & $73^{\circ} 09^{\prime} 10^{\prime \prime}$ & 5.9 & 2.24 \\
\hline $26 / 10 / 98$ & Concepción & $36^{\circ} 19^{\prime} 85^{\prime \prime}$ & $76^{\circ} 58^{\prime} 66^{\prime \prime}$ & 0.32 & $0.40^{c}$ \\
\hline
\end{tabular}

gasta, Coquimbo and Concepción Shelf upwelling ecosystems. During January 1997, mixed layer daily integrated GPP ranged from 0.12 to $9.3 \mathrm{~g} \mathrm{C} \mathrm{m}^{-2} \mathrm{~d}^{-1}$ while mixed layer integrated CR ranged from 0.06 to $1.7 \mathrm{~g} \mathrm{C}$ $\mathrm{m}^{-2} \mathrm{~d}^{-1}$ in the Antofagasta upwelling area. During July 1997 water column integrated GPP and CR values obtained at 1 coastal station of Antofagasta were 2.17 and $1.58 \mathrm{~g} \mathrm{C} \mathrm{m}^{-2} \mathrm{~d}^{-1}$ respectively. These values were very similar to the values measured in the COSMOS during November 1997, i.e. 2.8 and $1.46 \mathrm{~g} \mathrm{C} \mathrm{m}^{-2} \mathrm{~d}^{-1}$ respectively. During January 1998, the highest water column integrated GPP value for the northern Antofagasta area was $5.1 \mathrm{~g} \mathrm{C} \mathrm{m}^{-2} \mathrm{~d}^{-1}$. This value was obtained in the more coastal of the 3 stations sampled. At the Concepción Shelf water column integrated GPP ranged from 1.2 to $5.9 \mathrm{~g} \mathrm{C} \mathrm{m}^{-2} \mathrm{~d}^{-1}$ while integrated $\mathrm{CR}$ ranged from 2.24 to $3.2 \mathrm{~g} \mathrm{C} \mathrm{m}^{-2} \mathrm{~d}^{-1}$; in the more offshore station the integrated GPP and $C R$ were 0.32 and $0.4 \mathrm{~g} \mathrm{C} \mathrm{m}^{-2} \mathrm{~d}^{-1}$ respectively.

\section{GPP, CR, SST and chl a}

GPP and CR values were correlated with SST and chl $a$. In general the least productive waters were found at the lower $\left(<14^{\circ} \mathrm{C}\right.$, recently upwelled waters and upper SST range $\left(>21^{\circ} \mathrm{C}\right)$, corresponding to oceanic waters (Fig. 2). The greatest variability in production and respiration values was found in the intermediate temperature range ( $>15$ and $<18^{\circ} \mathrm{C}$ ). There was no significant linear correlation between SST and surface GPP; however a more consistent fit between SST and surface GPP was found by applying a reciprocal logarithm model to the data obtained from the Antofagasta upwelling system during the January and July cruises (Fig. 3, p $<0.01$ ). Within the Antofagasta upwelling ecosystem a significant linear correlation was found between chl $a$ and GPP $(\mathrm{r}=0.86 ; \mathrm{p}<0.01 ; \mathrm{n}=$ 15; $y=9.8 x+1.7 ;$ Fig. 4) and between chl $a$ and CR $(\mathrm{r}=0.7 ; \mathrm{p}<0.01 ; \mathrm{n}=15 ; \mathrm{y}=$ $1.4 x+2.7$; Fig. 5)
Fig. 2. Sea surface temperature (SST) versus surface gross primary produc-

tion (GPP) and community respiration (CR)

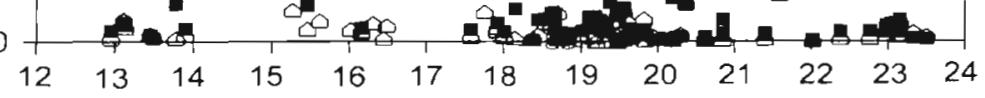




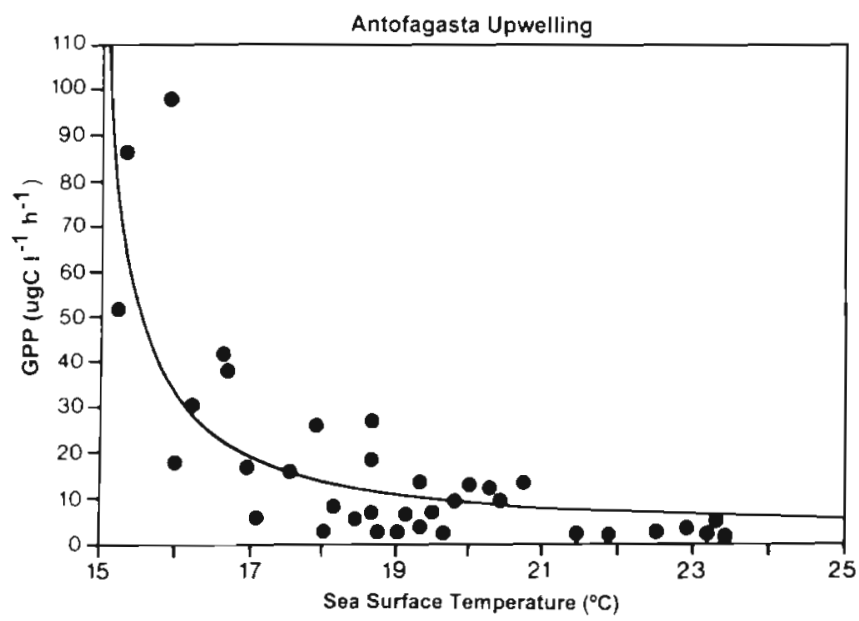

Fig. 3. Sea surface temperature (SST) versus surface gross primary production (GPP) in the Antofagasta upwelling ecosystem area

\section{PP in the Central-South fishing area of the HCS off Chile ( 35 to $\left.39^{\circ} \mathrm{S}\right)$}

Monthly mean PP values for the Central and Southern sections of the HCS off Chile are presented (Table 4). The monthly averages of $P P$ values fluctuate between 0.5 and $6 \mathrm{~g} \mathrm{C} \mathrm{m}^{-2} \mathrm{~d}^{-1}$. The winter months with the lowest photosynthetic rates were June, July and August
Table 4. Monthly averaged values of water column integrated primary production in the central-south fishing area of the Humboldt Current System off Chile

\begin{tabular}{|lccc|}
\hline Month & $\begin{array}{c}\text { Primary production } \\
\left(\mathrm{g} \mathrm{C} \mathrm{m}^{-2} \mathrm{~d}^{-1}\right)\end{array}$ & $\mathrm{n}$ & $\begin{array}{c}\% \text { of } \\
\text { annual Pp }\end{array}$ \\
\hline January & $5.7 \pm 3.3$ & 3 & 18.5 \\
February & 1.0 & 1 & 3.2 \\
March & 2.3 & 1 & 7.5 \\
April & $1.9 \pm 1.5$ & 2 & 6.3 \\
May & $1.8 \pm 1.4$ & 2 & 5.9 \\
June & $0.9 \pm 0.0$ & 2 & 2.8 \\
July & $0.5 \pm 0.4$ & 2 & 1.8 \\
August & $0.6 \pm 0.2$ & 4 & 1.8 \\
September & $4.9 \pm 0.7$ & 5 & 16.0 \\
October & $3.0 \pm 0.7$ & 5 & 9.7 \\
November & $6.1 \pm 3.4$ & 7 & 19.9 \\
December & $2.0 \pm 0.8$ & 2 & 6.5 \\
& & & \\
\hline
\end{tabular}

( $<1 \mathrm{~g} \mathrm{C} \mathrm{m}^{-2} \mathrm{~d}^{-1}$ ). During the rest of the year mean integrated production values were all $>1 \mathrm{~g} \mathrm{C} \mathrm{m}^{-2} \mathrm{~d}^{-1}$. The period between September and May contributed over $90 \%$ of the PP of the Central-South fishing area. In 2 cases extremely high PP and chl a values were found within the Gulf of Arauco (Fig. 1). On 24 and 29 November $1989 \mathrm{PP}$ values of 19.9 and $13.8 \mathrm{~g} \mathrm{C} \mathrm{m}^{-2} \mathrm{~d}^{-1}$ and $c h l a$ values of 75 and $64 \mu \mathrm{gl}^{-1}$ were measured. Annual $\mathrm{PP}$, estimated from the monthly mean $\mathrm{PP}$ values, was $0.93 \mathrm{~kg} \mathrm{C} \mathrm{m}^{-2} \mathrm{yr}^{-1}$ within the area sampled.

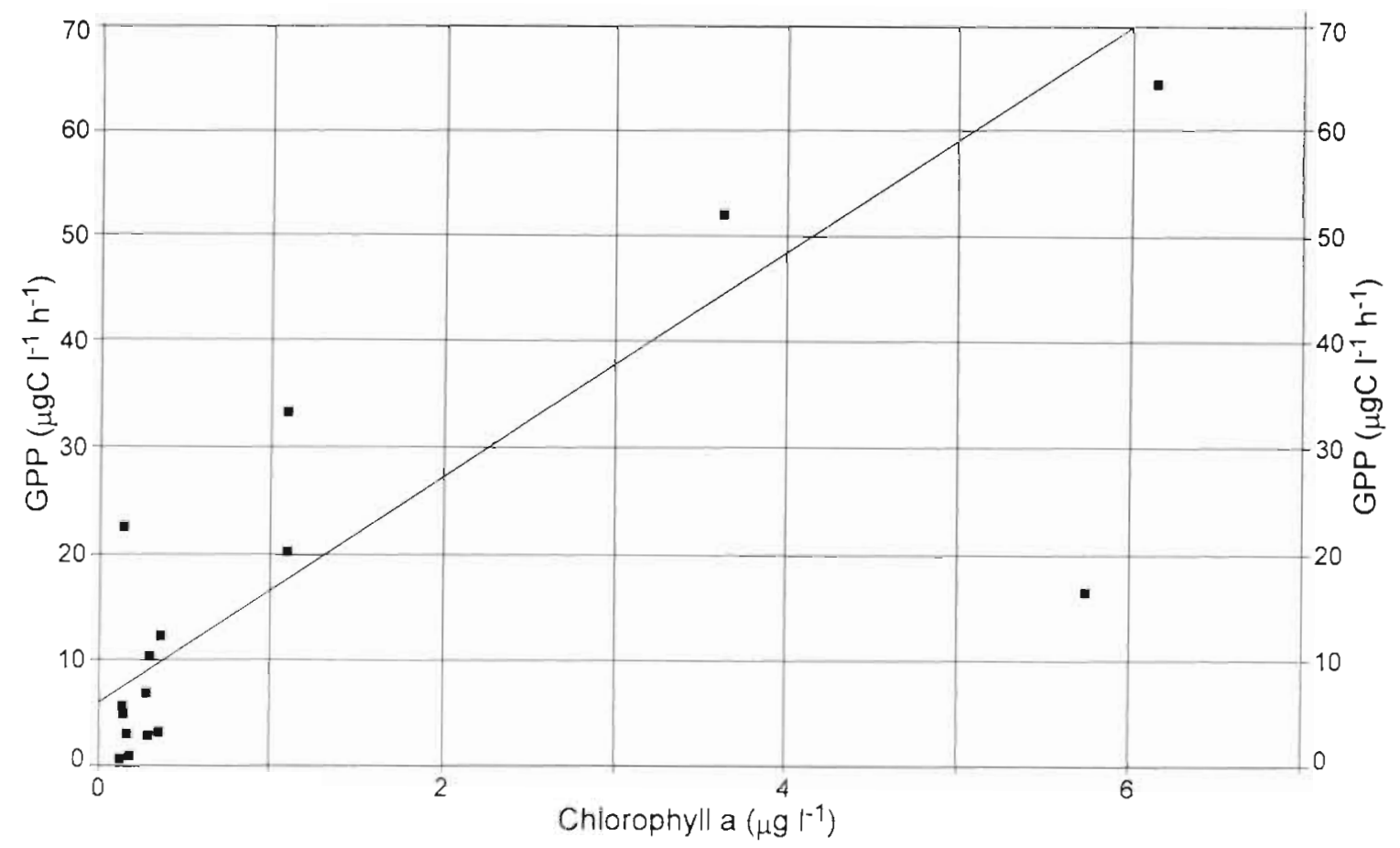

Fig. 4. Chlorophyll a (chl a) versus gross primary prodiction (GPP) in the Antofagasta upwelling ecosystem 


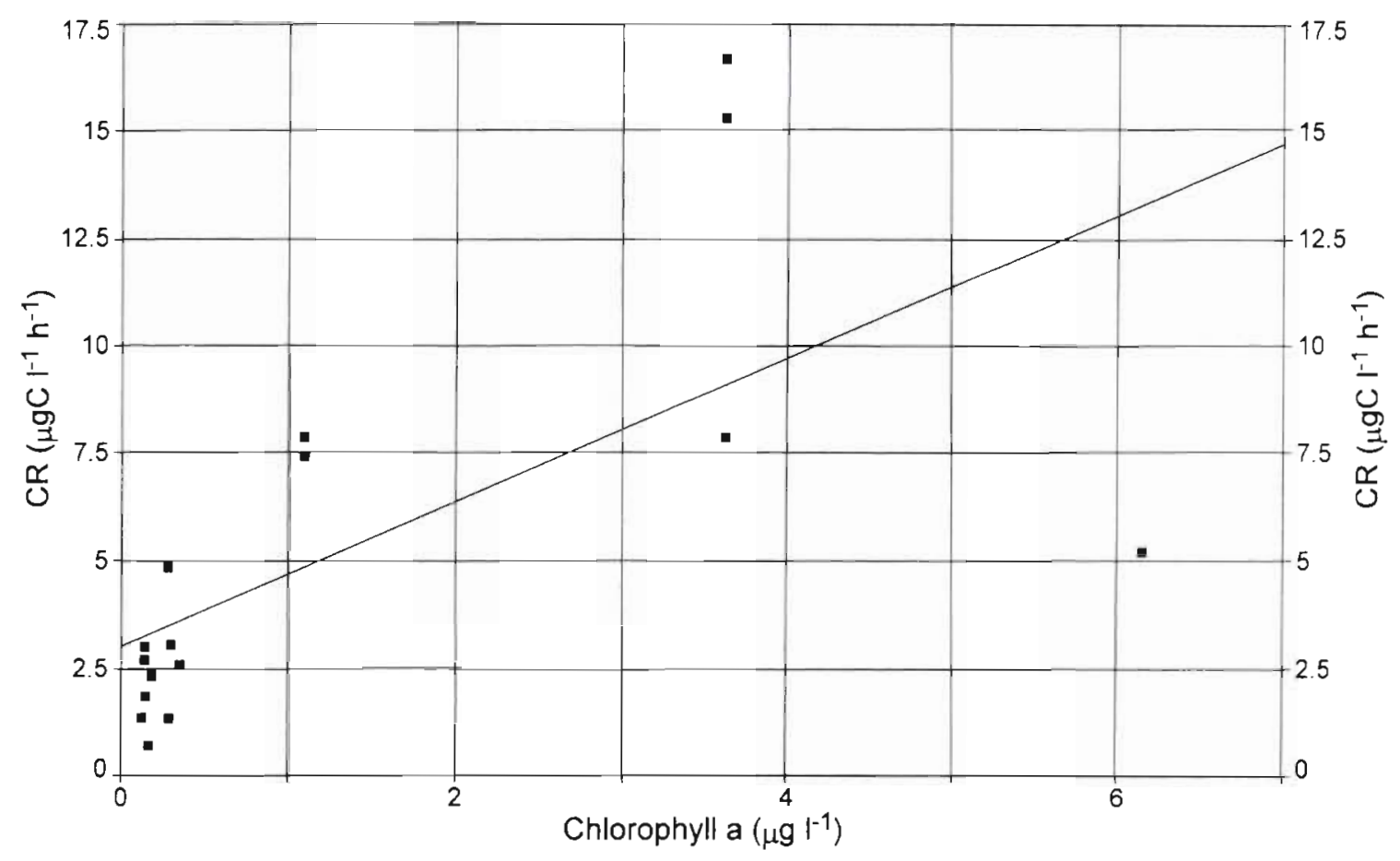

Fig. 5. Chlorophyll a ( $\mathrm{chl} \mathrm{a)} \mathrm{versus} \mathrm{community} \mathrm{respiration} \mathrm{(CR)} \mathrm{in} \mathrm{the} \mathrm{Antofagasta} \mathrm{upwelling} \mathrm{ecosystem}$

\section{DISCUSSION}

The data show important spatial and temporal fluctuations both in GPP and CR values within the HCS off Chile. The highest water column integrated GPP values were measured in the Central-South area $(19.9 \mathrm{~g}$ $\left.\mathrm{C} \mathrm{m}^{-2} \mathrm{~d}^{-1}\right)$ and off the Antofagasta upwelling center ( $9.3 \mathrm{~g} \mathrm{C} \mathrm{m}^{-2} \mathrm{~d}^{-1}$ ). The GPP value obtained in the southern zone represents one of the highest values ever reported for the open ocean.

The range of PP values found in the Antofagasta and the Central-South areas are similar to those reported for Peru (0.05 to $11.7 \mathrm{~g} \mathrm{C} \mathrm{m}^{-2} \mathrm{~d}^{-1}$ ) (Barber et al. 1971, Ryther et al. 1971, Harrison \& Platt 1981, Walsh 1981, Calienes et al. 1985). The integrated PP values obtained in Coquimbo at COSMOS and at OCEMOS during November 1997 are within the upper and intermediate ranges of values reported for the coastal 10.35 to $\left.2.9 \mathrm{~g} \mathrm{C} \mathrm{m}^{-2} \mathrm{~d}-1\right)$ and oceanic $\left(0.3\right.$ to $\left.1.3 \mathrm{~g} \mathrm{C} \mathrm{m}^{-2} \mathrm{~d}^{-1}\right)$ areas by Montecino et al. (1996) and Dellarossa et al. (in press). The usually lower biological activity described for the Coquimbo upwelling system was also reflected in low surface GPP and CR values measured during this study. Coquimbo consistently presents productivity values that are in the lower range of production values found in other upwelling centers within the HCS off Chile and off Peru. The low productivity of the Coquimbo upwelling system is also reflected in fishing landings, which in this area are about a third of those reported for Antofagasta and the Central-South fishing area of the HCS off Chile (SERNAPESCA 1994/7).

During July 1997 (El Niño conditions) the surface GPP and CR averages for the Antofagasta area showed a significant decline compared to the values obtained during January 1997. This decline in production rates during July 1997 could be due to a seasonal drop in the productivity rates and/or changes in hydrodynamical conditions during El Niño events. Changes in water column conditions during El Niño may have drastic effects on biological production rates, as previously reported by Barber \& Chavez (1983) and Barber et al. (1996). In agreement with this, a decrease in plankton respiration in the first $100 \mathrm{~m}$ of the water column was observed in the Antofagasta zone by Eissler \& Quiñones (1999) during El Niño 1997/98. Nonetheless during the January 1998 cruise in situ daily production values of 0.8 to $5.1 \mathrm{~g} \mathrm{C}$ $\mathrm{m}^{-2} \mathrm{~d}^{-1}$ were measured to the north of the Antofagasta upwelling system. The upper value $\left(5.1 \mathrm{~g} \mathrm{C} \mathrm{m}^{-2} \mathrm{~d}^{-1}\right)$ was measured within a narrow area of slightly colder water close to the coast. This high productivity value found during El Niño was unexpected and is indicative of the high variability of upwelling systems that can persist even under the influence of particularly accentuated El Niño events. To properly assess the full impact of El Niño on the biological production of the HCS, synoptic time series type of measurements are needed. 
It is important to consider that the mean surface GPP and CR values observed during January 1997 in the Antofagasta area may have been influenced by an anomalous drop in upwelling favourable winds in the months preceding El Niño 1997/98 (Ruttlant pers. comm.). This change in the wind field during pre-El Niño months resulted in diminished Ekman transport which can have negative consequences for the general productivity of the HCS off Chile before the arrival of warmer waters associated with El Niño events.

The integrated GPP values measured in Antofagasta ( 0.6 to $5.5 \mathrm{~g} \mathrm{C} \mathrm{m}^{-2} \mathrm{~d}^{-1}$ ) compare well with values (same order of magnitude) given by Marín et al. (1993) for the South Mejillones Bay area. However, the high production value of $2 \mathrm{~g} \mathrm{C} \mathrm{l}^{-1} \mathrm{~h}^{-1}$ observed by these authors within a bloom of Mesodinium was not repeated even though an extensive bloom of Mesodinium was sampled during January 1997

The mean monthly PP values obtained during this study in the Central-South fishing area 10.5 to $6 \mathrm{~g} \mathrm{C}$ $\mathrm{m}^{-2} \mathrm{~d}^{-1}$ ) during the 1988 to 1991 period are consistent with the range of the PP values reported for the Humboldt EBC system. However 2 high values (13.8 and $19.9 \mathrm{~g} \mathrm{C} \mathrm{m}^{-2} \mathrm{~d}^{-1}$ ) are among the highest reported for the open ocean. The annual PP value of $0.93 \mathrm{~kg} \mathrm{C} \mathrm{m}$ calculated for this area compares well with the annual production of $1 \mathrm{~kg} \mathrm{C} \mathrm{m} \mathrm{m}^{-2} \mathrm{yr}^{-1}$ estimated by Walsh (1981) for the Peruvian coast and explains to a large extent the magnitude of the fish landing in the area.

To date there are very few studies which describe the factors that control the levels and the variability of the PP within the HCS. The classical critical depth theory indicates that the availability of light and nutrients are the fundamental factors controlling PP in any given aquatic ecosystem. In the northern area of the HCS off Chile, light is probably not limiting throughout the year. In this area a close coupling between switches in production and nutrient availability should be expected. In agreement with this, Marin et al. (1993) showed that the seasonality in PP observed in the Mejillones Peninsula of Antofagasta is related to the intensification of upwelling favourable winds during the southern hemisphere spring and summer. If the occurrence of coastal upwelling is the single most important factor controlling the levels of production within the HCS off Chile then, for its northern area at least, we should expect a close coupling between PP and seasonal changes in the wind field. The above, however, seems to be true only for specific geographical areas. Coquimbo is known to be an area of strong upwelling; however the primary production of this region is consistently lower (Montecino et al. 1996, Dellarossa et al. in press, $O$. Ulloa unpubl. and data from this study) than that observed in other regions within the HCS off Chile. It is unlikely that chance alone can explain the low production values measured in Coquimbo. It is likely that the hydrodynamical regime of this area of persistent upwelling may preclude the development of strong production pulses and play an important role in determining the production levels observed. Possible explanations for the low productivity of the Coquimbo upwelling ecosystem include upwelling of water masses with different fertilising effects (Morales et al. 1996) and the deepening of the AESS water mass associated with the passage of coastal trapped waves (Shaffer et al. 1997). The low productivity of Coquimbo could also be explained by strong intrusions of oligotrophic oceanic waters into the coastal area off Coquimbo (Shaffer et al. 1995). However none of the above factors account for the fact that in Coquimbo low production persists even in the presence of AESS in the surface (G. Daneri pers, obs.). It is also worth noting that within the HCS off Chile the highest production values have been reported for enclosed areas, i.e. Bay of Mejillones (Marín et al. 1993), thus possibly suggesting that the role of water column stability needs to be taken into account.

The lowest surface GPP $\left(0.7 \pm 0.4 \mu \mathrm{g} \mathrm{Cl}^{-1} \mathrm{~h}^{-1}\right)$ and CR $\left(0.8 \pm 0.5 \mu \mathrm{g} \mathrm{Cl}^{-1} \mathrm{~h}^{-1}\right)$ values were measured within the oceanic region adjacent to the coastal upwelling zones. These values are 1 or 2 orders of magnitude lower than the production values usually found in more coastal areas. Since the area of low productivity was over 100 miles $(-160.9 \mathrm{~km})$ offshore, and since cold filaments extending from the coast have been detected up to 90 miles $(-144.8 \mathrm{~km})$ offshore (D. Figueroa pers. comm.) we propose that the 100 miles should be considered as the outer limit of coastal upwelling influence. Within the oceanic realm, slightly enhanced biological production was found in the Nazca Ridge that separates the Chilean and Peruvian deep basins.

During this study an attempt was made to apply a mathematical model to correlate SST to surface GPP. The SST, in upwelling areas, can be used as a proxy indicator for both water column stratification and nutrient content. So we hoped to obtain a normal type continuous function describing low production in both cold, recently upwelled waters and in warmer oceanic waters (at both tails of the curve) and higher production values in the intermediate temperature range $\left(<15^{\circ} \mathrm{C}>18^{\circ} \mathrm{C}\right)$. However no mathematically significant model could be found due to the high scatter observed within the intermediate temperature range. This is probably a reflection of both latitudinal changes in upwelled SST and differences in the fertilising capacity of the upwelled subsurface waters (Morales et al 1996). A consistent fit was found, however, between SST and GPP using the data obtained within the Antofagasta upwelling system. For the same area significant correlations were found between GPP and chl $a$ and between CR and chl $a$. 
Acknowledgements. The professional assistance of the Abate Molina crew is gratefully acknowledged. This research was funded by JGOFS/SIDA-SAREC/CONYCIT, Project Sectorial Antofagasta FONDECYT 596002/CONICYT and FONDAPHumboldt.

\section{LITERATURE CITED}

Ahumada R (1989) Producción y destino de la biomasa fitoplantónica en un sistema de bahías en Chile central: una hipótesis. Biol Pesq 18:53-66

Alheit J, Bernal PA (1993) Effects of physical and biological changes on the biomass yield of the Humboldt Current System. In: Sherman K, Alexander LM, Gold BD (eds) Large marine ecosystems. American Association for the Advancement of Science Press, Washington, DC, p 53-68

Arcos DF, Salamanca M (1984) Distribución de clorofila y condiciones oceanográficas superficiales frente a Chile Central (Latitudes $32^{\circ} \mathrm{S}-38^{\circ} \mathrm{S}$, febrero 1982). Biol Pesq 13:5-14

Barber RT, Chavez FP (1983) Biological consequences of El Nin̄o. Science 222:1203-1210

Barber RT, Dugdale RC, MacIsaac JJ, Smith RL (1971) Variation in phytoplankton growth associated with source and conditioning of upwelling water. Invest Pesq 35: $171-194$

Barber RT, Sanderson MP, Lindley ST, Chai $F$, Newton J, Trees CC, Foley DG, Chavez FP (1996) Primary productivity and its regulation in the equatorial Pacific during and following the 1991-1992 El Niño. Deep-Sea Res 43 933-969

Bernal PA, Robles FL, Rojas O (1982) Variabilidad física y biológica en la region meridional del sistema de corrientes Chile-Perú. Monogr Biol 2:75-102

Calienes R, Guillén O, Lostaunau N (1985) Variabilidad espacio-temporal de clorofila, producción primaria y nutrientes frente a la costa Peruana. Bol Inst Mar Perú OEA 10(1): $1-12$

Carrit DE, Carpenter HJ (1966) Comparison and evaluation of currently deployed modifications of the Winkler method for determining dissolved oxygen in seawater: a NASCO Report. J Mar Res 24:287-318

Dellarossa V, Daneri G, Quiñones R, Ulloa O (in press) Producción primaria y biomasa fraccionada por tamaño en la zona de Coquimbo, Chile. (Rev Chilena de Hist Natural)

Eissler Y, Quiñones RA (1999) Microplanktonic respiration off Antofagasta (Northern, Chile) during pre-ENSO and ENSO conditions (1997-98). J Plankton Res 21:2263-2283

Fee E (1984) Programa computacional (BASIC) para calcular productividad primaria integral diariamente. In: Nahamonde $\mathrm{N}$, Cabrera S (eds) Embalses, fotosintesis y productividad primaria, Alfabeta Impr, Univ de Chile, Santiago, p 225-227

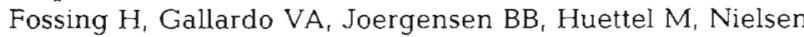
LP, Schultz H, Canfield DE, Forster S, Glud RN, Gundersen JK, Kuever J, Ramsing NB, Teske A, Thamdrup B, Ulloa $O$ (1995) Concentration and transport of nitrate by the mat-forming sulphur bacterium Thioploca. Nature 374:713-715

Harrison G, Platt T (1981) Primary production and nutrient

Editorial responsibility: Otto Kinne (Editor),

Oldendorf/Luhe, Germany fluxes off the northern coast of Perú: a summary. Bol Inst Mar Perú Ext ICANE, p 130-143

Holm-Hansen O, Lorenzen CJ, Holmes RW, Strickland JDH (1965) Fluorometric determination of chlorophyll. J Cons Int Explor Mer 30:3-15

Jury MR, MacArthur CY, Brundrit B (1990) Pulsing of the Benguela upwelling region: large-scale atmospheric controls. S Afr J Mar Sci 9:27-41

Knap AH, Michaels AF, Dow RL, Johnson RJ, Gundersen $K$, Sorensen JC, Clos AR, Howse FA, Hammer M, Bates N, Doyle A, Waterhouse T (1993) US Joint Global Flux Study, Bermuda Atlantic Time-series Study. BATS Method Manual, Version 3, Woods Hole, MA

Marín V, Rodriguez L, Vallejo L, Fuenteseca J, Oyarce E (1993) Efectos de la surgencia costera sobre la productividad prinaria primaveral de Bahía Mejillones del Sur (Antofagasta, Chile). Rev Chilena Hist Nat 66:479-491

Montecino V, Pizarro G, Quiroz D (1996) Dinámica fitoplantónica en el sistema de surgencia frente a Coquimbo $\left(30^{\circ} \mathrm{S}\right)$ a través de la relación funcional entre fotosíntesis e irradianza (P-I). Gayana Oceanol 4(2):139-151

Morales CE, Blanco JL, Braun M, Reyes H, Silva N (1996) Chlorophyll-a distribution and associated oceanographic conditions in the upwelling region off northern Chile during the winter and spring 1993. Deep-Sea Res 43:267-289

Peterson WT, Arcos D, Mc Manus GB, Dam H, Bellantoni D, Johnson TH, Tiselus P (1988) The nearshore zone during costal upwelling: daily variability and coupling between primary and secondary production off Central Chile. Prog Oceanogr 20:1-40

Ryther JH, Menzel DW, Hulburt EM, Lorenzen CJ, Corwin N (1971) Production and utilization of organic matter in Perú coastal current. Invest Pesq 35:43-59

SERNAPESCA (1994-1997) Anuario Estadístico de Pesca Servicio Nacional de Pesca (SERNAPESCA), Ministerio de Economía, Fomento y Reconstrucción, Santiago

Shaffer G, Salinas S, Pizarro O, Vega A, Hormazabal S (1995) Currents in the deep ocean off Chile $\left(30^{\circ} \mathrm{S}\right)$. Deep-Sea Res 42:425-436

Shaffer G, Pizarro O, Durjfeld L, Salinas S, Rutllant J (1997) Circulation and low frequency variability near the Chilean coast: remotely forced fluctuations during the 1991-92 El Nin̄o. J Phys Oceanogr 21:217-235

Silva N, Konow D (1975) Contribución al conocimiento de las masas de agua en el Pacífico Sudoriental. (Expedición Krill, Crucero 3-4, Julio-Agosto 1974). Rev Com Perm Pac Sur 3:63-75

Strickland JDH (1960) Measuring the production of marine phytoplankton. Bull Fish Res Board Can 122:1-72

Strickland JDH, Parsons TR (1972) A practical handbook of seawater analysis. Bull Fish Res Board Can 167

Thomas AC, Huang F, Strub PT, James C (1994) Comparison of the seasonal and interannual variability of phytoplankton pigment concentrations in the Perú and California Current systems. J Geophys Res 99:7355-7370

Walsh JJ (1981) A carbon budget for overfishing off Perú. Nature 290:300-304

Williams PJLeB, Jenkinson NW (1982) A transportable microprocessor-contrlled precise Winkler titration suitable for field station and shipboard use. Limnol Oceanogr 27 : 576-584

Submitted: July 23, 1998; Accepted: September 14, 1999 Proofs received from author(s): April 14, 2000 